\title{
O olhar tropicalista sobre a cidade de São Paulo*
}

\section{The tropicalim looks over São Paulo city}

\author{
Marcos napolitano \\ Professor do Departamento de História da Universidade de São Paulo (USP) \\ Bolsista Produtividade do $\mathrm{CNPq}$ \\ Rua do Lago, 717 - Butantã - Cidade: São Paulo -SP - CEP: 05508-900 \\ marcos.napoli@uol.com.br
}

\begin{abstract}
RESUMO A Tropicália pode ser considerada um movimento cultural ancorado em São Paulo, pois foi a partir desta cidade que ele explodiu para o mundo, constituindo-se num dos capítulos mais importantes de sua história cultural. Foi resultante de uma conjuntura sociocultural específica, a agitação em torno dos festivais da canção e da retomada do ethos vanguardista nos anos 1960. O movimento tropicalista foi rapidamente enquadrado na tradição de ruptura que marcou a cidade de São Paulo a partir da Semana de Arte Moderna de 1922.
\end{abstract}

Palavras-chave Tropicália, Brasil República, Cultura brasileira

ABSTRACT "Tropicalism" may be considered a cultural movement anchored in São Paulo, for it was from that city that it burst onto the world, constituting one of the most important chapters of its cultural history. It was the result of a specific socio-cultural set of circumstances, the agitation around the song festivals and the return to the avant-garde ethos of the

Artigo recebido em: 14/01/2005- Aprovado em: 21/03/2005 
Sixties. The tropicalist movement was rapidly placed within the tradition of rupture notable for the city of São Paulo beginning with the Modern Art Week of 1922.

Key words Tropicalism, Brazilian Republic, Brazilian culture

Apesar de a maioria dos tropicalistas ser baiana e do movimento ter sido batizado no Rio de Janeiro, a Tropicália pode ser considerada um movimento cultural ancorado em São Paulo, pois foi a partir desta cidade que ele explodiu para o mundo, constituindo-se num dos capítulos mais importantes de sua história cultural. Produto de uma conjuntura sociocultural específica, a agitação em torno dos festivais da canção e da retomada do ethos vanguardista nos anos 1960, o movimento tropicalista foi rapidamente enquadrado na tradição de ruptura que marcou a cidade de São Paulo a partir da Semana de Arte Moderna de 1922, definindo ao lado do Concretismo, uma dada linhagem histórica da vanguarda paulistana e brasileira. Não por acaso, Caetano Veloso, aproveitando a deixa do poeta concretista Augusto de Campos numa entrevista concedida a este em 1968, proferiu: "o Tropicalismo é um neo-antropofagismo". Pouco importava se Caetano e outros tropicalistas ilustres pouco conhecessem a obra de Oswald de Andrade ${ }^{1}$. Importava sim, a tradição cultural (ou afinidade eletiva) que se afirmava, como uma chave de leitura da cultura brasileira do século XX, pensada a partir da "moderna tradição" paulistana, sintetizada na tríade Antropofagia - Poesia Concreta - Tropicália. A rigor, o movimento tropicalista durou do final de 1967 até meados de 1969, mas seu espírito de pesquisa passou a fazer parte da música popular e da cultura brasileiras desde então.

Entretanto, se a Tropicália, enquanto movimento cultural, cresceu e apareceu na cidade, e a cidade a acolheu como seu palco e platéia de primeira hora, os compositores tropicalistas não chegaram a privilegiar o "charme discreto de suas meninas" e a "dura poesia concreta de suas esquinas" como material poético inspirador para a maior parte das suas canções. Mas é bom lembrar que se é lícito supor que há uma linha de crítica cultural consolidada pela Tropicália, ela se baseia na tentativa de equacionar as contradições do Brasil e seus dilemas históricos, entre outros, o de ser um país arcaico-moderno, cosmopolita-provinciano, industrializado-subdesenvolvido. Obviamente, esta equação não tem resultado "zero", produzindo deficits socioculturais que foram problematizados pelo movimento. Nenhum lugar melhor do que São Paulo para

1 VELOSO, Caetano. Verdade Tropical. São Paulo: Cia das Letras, 1998, p.241-262 
potencializar a experiência destas dicotomias, num momento mesmo em que a cidade consolidava sua posição de capital do Brasil industrializado e assumia, ao menos momentaneamente, um lugar privilegiado no campo musical, sediando os lendários festivais da canção da TV Record. Assim, São Paulo pode ter sido uma cidade-musa que, paradoxalmente, não foi diretamente cantada pela Tropicália, ao menos durante a fase heróica do movimento (1967/1969), mas que sem dúvida forneceu o ambiente acolhedor para que o espírito iconoclasta e as ousadias experimentalistas dessem frutos ${ }^{2}$.

A cidade de São Paulo, historicamente, tem sido marcada por um ambiente artístico aberto às rupturas e novidades e isso contribuiu para regar o jardim brutal dos tropicalistas. A experiência cultural paulistana propiciou um contraponto instigante em relação a outros ambientes culturais brasileiros. A cidade do Rio de Janeiro e a região da Bahia, por exemplo, formaram a geografia cultural mais citada pelos compositores tropicalistas (Tropicália, Enquanto seu lobo não vem, Domingo no Parque, Paisagem Útil, Luzia Luluza, Aquele Abraço, Hino ao Senhor do Bonfim, Geléia Geral, Onde Andarás, Superbacana). Em contraste, a única referência direta a São Paulo em canções compostas durante a periodização clássica do movimento (1967-1969) foi São São Paulo (Tom Zé, 1968). Tom Zé, aliás, seria o mais paulistano dos tropicalistas baianos, incorporando a cidade como elemento inspirador de canções, principalmente nos seus LPs de 1968, 1970 e 1972. A cidade teria que esperar até 1978 para receber a homenagem definitiva em forma de canção "tropicalista", em Sampa de Caetano Veloso.

Se a cidade de São Paulo não foi uma referência poética privilegiada e diretamente citada nas letras de canções tropicalistas, qual teria sido seu papel histórico para o movimento? Neste ponto, arriscaríamos uma hipótese: se a Bahia e o Rio de Janeiro foram os engenhos que forneceram os símbolos clássicos de brasilidade, trabalhado nas canções como "relíquias do Brasil", São Paulo foi a usina que permitiu aos tropicalistas radicalizarem a desconstrução paródica destes mesmos símbolos. A "cidade-qualquer-coisa", sem características reconhecidas de "brasilidade" e, ao mesmo tempo, ponto-de-fusão de todos os brasis, propiciou uma experiência sociocultural plena para a explosão da vanguarda iconoclasta, na medida em que boa parte do seu ambiente urbano e sua elite cultural não se obrigava a ser a tradução ideológica da "autêntica cultura brasileira", ao contrário do clima cultural hegemônico em Salva-

2 DUNN, Christopher. Brutality Garden: tropicália and the emergence of a Brazilian counterculture. Chapel Hill: University of North Carolina Press, 2001, 100-109. O autor destaca como a experiência urbana de São Paulo estimulou os tropicalistas a partir da percepção de questões como a modernização desigual, o contraste entre tecnologia e artesanato, além de novas percepções de espaço e afetividade dentro das relações sociais da grande metrópole capitalista 
dor ou no Rio de Janeiro ${ }^{3}$. Além desse aspecto mais amplo, é importante lembrar que foi na cidade que o Grupo Baiano tomou contato com músicos experimentais, como os maestros Júlio Medaglia e Rogério Duprat e com a nascente cena pop brasileira, sobretudo com os Mutantes, grupo que temperou a sonoridade tropicalista com o melhor do rock.

Como já afirmamos, a Tropicália foi batizada no Rio de Janeiro. O primeiro batismo: em julho de 1967 Hélio Oiticica apresentava sua obra homônima na Exposição Nova Objetividade Brasileira no Museu de Arte Moderna, do Rio de Janeiro. O segundo batismo: em fevereiro de 1968 um grupo de artistas e intelectuais cariocas, a título de deboche, assinou e publicou um manifesto intitulado "Cruzada Tropicalista", publicado na coluna de Nelson Motta, no jornal Última Hora. Este manifesto, ironicamente, acabou consagrando a expressão, logo depois assumida pelo "grupo baiano" que, desde o III Festival da TV Record, em setembro de 1967, já agitava os padrões de "bom gosto" da Música Popular Brasileira, predominantemente nacionalista e de esquerda. Antes disso, podemos dizer que a Tropicália teve sua gênese na Bahia, podendo ser considerada um dos produtos da efervescência cultural que tomou conta de Salvador no final dos anos 1950 e que aglutinou jovens criadores em torno do ambiente universitário soteropolitano que permitiu o encontro da cultura popular nordestina com a vanguarda internacional mais ousa$\mathrm{da}^{4}$.

Se o parto foi na Bahia e o batismo no Rio de Janeiro, os primeiros passos da Tropicália aconteceram em São Paulo. Num primeiro momento no teatro, com a retumbante temporada do Rei da Vela, peça de Osvald de Andrade, encenada pela primeira vez em 1967, pelo Grupo Oficina. No manifesto assinado pelo Grupo, em 04 de setembro de 1967, surgia um dos princípios fundamentais que marcaria a crítica cultural tropicalista: "Tudo procura transmitir essa realidade de muito barulho por nada, onde todos os caminhos tentados para superá-la até agora se mostram inviáveis. Tudo procura mostrar o imenso cadáver que tem sido a não-história do Brasil destes últimos anos, à qual nós todos acendemos nossa vela para trazer, através de nossa atividade cotidiana, alento. 1933-1967: são 34 anos. Duas gerações pelo menos levaram suas velas. E o corpo continua gangrenando".

A história como farsa e o imperativo da ruptura estética a partir da paródia e da ironia, estão presentes neste manifesto teatral e logo seriam associados aos procedimentos poéticos e às performances desenvolvi-

3 A discussão sobre este processo complexo foge aos limites deste texto, mas arriscamos dizer que a formatação do conjunto de símbolos de brasilidade teve um de seus capítulos mais importantes no primeiro período de governo varguista, entre 1930 a 1945, quando o Rio e a Bahia consagraram-se como lugares- síntese da brasilidade "autêntica".

4 RISÉRIO, Antonio. Avant-Garde na Bahia. Fundação Lina Bo Bardi, 1995 
das pelos músicos do "grupo baiano"5. A retomada osvaldiana e o recurso à alegoria como elemento de descontrução das grandes narrativas ideológicas sobre o Brasil, à esquerda e à direita, surgiam como princípios reconhecíveis do movimento, ainda que teatro e canção dialogassem com tradições e problemáticas culturais diferentes ${ }^{6}$.

Quase simultaneamente ao sucesso da montagem do Rei da Vela, Caetano Veloso, Gilberto Gil e os Mutantes apresentavam-se no III Festival de MPB da TV Record de São Paulo, defendendo, respectivamente, Alegria, Alegria e Domingo no Parque. Entre outras inovações poéticas, as duas canções deslocavam a geografia poético-política da música de festival do sertão e do morro, mitificados pela esquerda nacionalista como os lugares da revolução brasileira, para ambiências mais urbanas e modernas. Surgia a "canção tropicalista". Conforme Celso Favaretto: "É possível constatar mais intensamente esta eficácia da intervenção tropicalista se a gente se curvar sobre a construção das imagens tropicalistas, basicamente sobre o processo alegórico. As canções tropicalistas resultam de um processo construtivo que agencia imagens que resultam da justaposição de materiais diversos, de elementos díspares, provocando um efeito de obscuridade, de estranheza, como se fosse um sonho. Cena alusiva que alegoriza o Brasil, esta cena desmontada evidencia as aberrações da persistência dos arcaísmos, das deformações no processo de modernização da sociedade ${ }^{7}$.

O personagem poético de Alegria, Alegria, um jovem "sem lenço, sem documento", vaga por uma metrópole moderna (São Paulo?), olhando as "bancas de revista", perdendo-se entre as personalidades da mídia, tomando coca-cola ("o líquido negro do imperialismo", como a esquerda dizia) e decidindo-se entre casar e cantar na TV. O "coração do Brasil" já não pulsava apenas no meio rural, mas nas grandes cidades modernas e contrastantes, produtos de uma modernização sócio-econômica acelerada e excludente. E qual lugar onde estas questões estariam mais potencializadas a não ser em São Paulo? Já Domingo no Parque, embora faça referência direta à Salvador (Ribeira, Boca do Rio), desmistifica o povo-herói da esquerda nacionalista, tecendo um painel lírico e patético, a um só tempo, ao contar a história do triângulo amoroso de Maria, José e João, três personagens proletários que, distantes de qualquer vocação épica e revolucionária, põem suas vidas a perder por paixão e ciú-

5 Apesar de frequentemente ser associado ao movimento, devido ao impacto do alegórico e descontrutivo Terra em Transe, Glauber Rocha sempre renegou tal associação, considerando a Tropicália um movimento vazio politicamente.

6 NAPOLITANO, Marcos. "A arte engajada e seus públicos". Estudos Históricos, 28, Rio de Janeiro, 103-124, 2001

7 FAVARETTO, c. "Tropicália: política e cultura" IN: Naves, S. et alli. Do samba canção à tropicália. RelumeDumará / FAPERJ, 2003, 246-247 
mes. Musicalmente, as duas canções incorporaram timbres inovadores. Alegria, Alegria, uma marchinha-pop, incorpora a guitarra elétrica do rock e Domingo no Parque cruzou a levada roqueira dos Mutantes com o arranjo orquestral conduzido pela batuta do maestro Rogério Duprat, herdeiro do movimento Música Nova. O mesmo maestro que, em 1965, tinha lançado num "recital" ao pé da estátua do Borba Gato, no bairro de Santo Amaro, o M.A.R.D.A (Movimento de Arregimentação Radical em Defesa da Arte), cujo espírito dadaista seria retomado pela Tropicália ${ }^{8}$.

Ao lado deste espírito antropofágico e dadaísta, a vanguarda paulistana de linhagem mais construtiva, representada pela Poesia Concreta, logo adotou os jovens músicos baianos, percebendo neles a possibilidade de realizar o sonho osvaldiano, de fazer as massas comerem o "biscoito fino" da arte experimental. Caetano Veloso, ao lado de Gilberto Gil, na condição de ídolos pop da nascente indústria cultural brasileira, foram vistos como os arautos deste novo momento da vanguarda paulista e brasileira. A paulicéia, naqueles idos de 1968, parecia retomar sua vocação para o desvairio, devidamente filtrado pela baianidade hegemônica na Tropicália. Caetano, singelamente, afirmou em suas memórias: "era gostoso viver no coração de uma cidade grande, entre grandes edifícios" ". A cidade, por seu turno, temperou o olhar tropicalista sobre o Brasil, amplificando a tensão "moderno-arcaico", constituinte da perspectiva tropicalista. Esta mediação deu-se não apenas devido ao ambiente urbano tensionado pelo choque arcaico-moderno, mas pelo contato com parte dos artistas e críticos paulistanos filiados à tradição de vanguarda, acalentada pela cidade desde os anos 20.

No primeiro semestre de 1968, o Tropicalismo, paralelamente à sua faceta de movimento cultural, consolidava-se como atitude e moda permitindo que um país periférico como o Brasil tivesse uma chave de leitura para se inserir na contracultura ocidental, disseminada através dos Estados Unidos e da Europa. A multinacional Rhodia tornou-se patrocinadora do movimento, aproveitando para divulgar seus novos tecidos, bases para confecções coloridas dentro da estética psicodélica, uma das vertentes operadas pelo tropicalismo. A mídia dava ampla cobertura para os personagens tropicalistas, principalmente Caetano Veloso, eleito o mais novo enfant terrible da cultura brasileira. Mundanismo e arte encontravam-se sob a égide do movimento, que em meio a tanto barulho consagrou-se junto à opinião pública e à mídia. Num certo sentido, várias manifestações diferenciadas entre si, mas tendo como objetivo co-

8 Para uma análise detalhada do experimentalismo musical da Tropicália ver VILLAÇA, Mariana Martins. Polifonia Tropical: experimentalismo e engajamento na música popular (Brasil e Cuba, 1967/1972). São Paulo, Humanitas/História Social-USP, 2004

9 VELOSO, Caetano. Op.cit. p. 200 
mum o de problematizar a realidade brasileira fora dos padrões do engajamento de esquerda, acabaram sendo vistas como tropicalistas, emprestando ao termo um sentido tão amplo quanto confuso.

No segundo semestre de 1968, o tropicalismo musical atingiu o seu auge. A cidade de São Paulo assistiu a alguns dos capítulos mais memoráveis da aventura tropicalista.

Em junho, a Faculdade de Arquitetura e Urbanismo da USP assistiu o debate entre a "tendência Chico", ampla maioria, e a "tendência Caetano". Em agosto, a boate "Som de Cristal", reduto popular de dança de salão, abrigou o show "Vida, paixão e banana da Tropicália", que promoveu o encontro dos jovens tropicalistas com velhos artistas considerados "cafonas" pelo bom gosto vigente na MPB: Dircinha Batista e Dalva de Oliveira. Vicente Celestino, convidado especial, não pode comparecer pois faleceu naquele mesmo dia. O evento foi o lançamento oficial do LP "Panis et Circensis", disco-manifesto do Tropicalismo musical. Em setembro, Caetano Veloso proferiu seu memorável discurso "anti-patruIhas" no palco do TUCA (Teatro da Pontifícia Universidade Católica de São Paulo), enquanto os Mutantes tocavam de costa para a platéia e um hippie norte-americano fazia performances corporais no palco. Uma cena que em nada ficaria devendo ao clima da Semana de Arte Moderna de 1922:

"Mas é isso que é a juventude que diz que quer tomar o poder? Vocês tem
coragem de aplaudir este ano uma música que vocês não teriam coragem de
aplaudir no ano passado; são a mesma juventude que vai sempre, sempre,
matar amanhã o velhote inimigo que morreu ontem! Vocês não estão enten-
dendo nada, nada, nada , absolutamente nada. (...) Mas que juventude é
essa, que juventude é essa? Vocês jamais conterão ninguém! Vocês são iguais
sabe a quem? São iguais sabe a quem? - tem som no microfone? - Àque-
les que foram ao Roda Viva e espancaram os atores. Vocês não diferem em
nada deles, vocês não diferem em nada! (...) O problema é o seguinte: vocês
estão querendo policiar a música brasileira! (...) Gilberto Gil está comigo pra
acabarmos com o festival e com toda a imbecilidade que reina no Brasil.
Acabar com isso tudo de uma vez! Nós só entramos em festival pra isso, não
é Gil? Não fingimos, não fingimos que desconhecemos o que seja festival,
não. Nós, eu e ele, tivemos a coragem de entrar em todas as estruturas e sair
de todas, e vocês? E vocês? Se vocês em política forem como são em esté-
tica, estamos feitos!"

Em novembro, a TV TUPI de São Paulo abriu espaço para as performances na telinha, estreando o programa "Divinos e Maravilhosos", no qual a trupe tropicalista exercitava suas performances e provocações ao bom gosto e ao comportamento conservador, da esquerda e da direita. Um dos momentos mais memoráveis e impactantes, aconteceu no sombrio Natal daquele ano, quando Caetano cantou "Noite Feliz" com uma arma apontada para a própria Cabeça. Alguns dias antes, é bom lem- 
brar, o governo militar promulgava o Ato Institucional n 5, uma arma jurídica apontada para a cabeça do cidadão brasileiro.

No final de 1968, O IV Festival de MPB da TV Record, o maior evento musical da cidade, foi o grande palco de consagração do Tropicalismo. Além da estreante Gal Costa defender "Divino, Maravilhoso", de Caetano e Gil, Tom Zé ganhou o festival defendendo uma marchinha que ao mesmo tempo homenageava e criticava a cidade de São Paulo: "São São Paulo"10:

São São Paulo quanta dor
São São Paulo meu amor

São oito milhões de habitantes

De todo canto e nação

Que se agridem cortesmente

Correndo a todo vapor

E amando com todo ódio

Se odeiam com todo amor

São oito milhões de habitantes

Aglomerada solidão

Por mil chaminés e carros

Gaseados a prestação

Porém com todo defeito

Te carrego no meu peito

São São Paulo quanta dor

São São Paulo meu amor

Salvai-nos por caridade

Pecadoras invadiram

Todo o centro da cidade

Armadas de ruge e batom

Dando vivas ao bom humor

Num atentado contra o pudor

A família protegida

O palavrão reprimido

Um pregador que condena

Um festival por quinzena

porém com todo defeito

Te carrego no meu peito

São São Paulo quanta dor

São São Paulo meu amor

10 Ver a análise de Charles PERRONE em "Performing São Paulo: vanguard representations of a Brazilian Cosmópolis", Latin American Music Review, 23/1, 60-78, 2002. Neste artigo, o autor propõe uma análise da canção de Tom Zé, destacando a visão de São Paulo marcada pelo "estranhamento, aversão e fascinação", resultando numa visão cáustica e afetiva a um só tempo. 


\author{
Santo Antonio foi demitido \\ E os ministros de Cupido \\ Armados da eletrônica \\ Casam pela tevê \\ Crescem flores de concreto \\ Céu aberto ninguém vê \\ Em Brasília é veraneio \\ No Rio é banho de mar \\ O país todo de férias \\ E aqui é só trabalhar \\ Porém com todo defeito \\ Te carrego no meu peito \\ São São Paulo quanta dor \\ São São Paulo meu amor
}

Enquanto Tom Zé interpretava a canção, o grupo que o acompanhava fazia uma performance gestual, fantasiados com roupas que lembravam alguns dos tipos mais relacionados à cidade de São Paulo: a melindrosa, o almofadinha, o caipira e o bandeirante. Num certo sentido, estas fantasias remetiam ao contexto dos anos 1920, quando o movimento modernista demarcou uma tradição cultural da cidade. Se a letra de Tom Zé falava a partir de um olhar contemporâneo sobre a metrópole, a performance do grupo que o acompanhava remetia a personagens simbólicos da identidade cultural paulista e paulistana, tal como cristalizadas pela "moderna tradição" das primeiras décadas do século XX.

A letra da canção também dialogava com certos lugares-comuns sobre a cidade, explorando seus contrastes (multidão-solidão, moralismo - licenciosidade, fé - utilitarismo, entre outras). Um dos trechos censurados da letra original obrigou ao compositor escrever "um festival por quinzena" (alusão aos festivais da canção na TV), no lugar de "uma bomba por quinzena", aludindo ao início da luta armada contra o regime, que tinha em São Paulo um dos seus focos mais radicais. Na última estrofe, o "Santo Antonio casamenteiro", elemento de uma cultura popular provinciana, funde-se com a citação da imagem televisual, destacando o choque arcaico-moderno e provinciano-cosmopolita, tensões que marcavam a vida paulistana e brasileira do período. A seguir a imagem do trabalho, outro lugar comum sobre a cidade, contrastava com o "ócio" de outras cidades e regiões brasileiras, em outro trecho que sofreu ação da censura, pois originalmente dizia que em Brasília, estava "todo mundo de férias". Em que pese esta visão ácida sobre a cidade e seus contrastes, todas as estrofes repousam numa visão amena e afetiva, uma das marcas do olhar lírico de Tom Zé sobre a cidade de São Paulo. 


\section{Tom Zé: a visão divina e maravilhosa da magelópole}

Como já destacou Charles Perrone ${ }^{11}$, Tom Zé vê São Paulo a partir de uma perspectiva paradoxal, marcada por uma mistura de "estranhamento, aversão e fascinação", resultando numa visão cáustica e afetiva a um só tempo. A experiência da multidão solitária, o moralismo da Tradicional Família Paulistana, a mídia e a obsessão pelo trabalho, são elementos condutores da visão poética de Tom Zé, que culmina numa visão até amena, se quisermos, destas contradições. Aliás, enquanto nas músicas de Gil e Caetano, as imagens predominantes eram as da Bahia e do Rio de Janeiro, com algumas alusões genéricas à vida urbana, Tom Zé notabilizou-se como o compositor tropicalista que mais cantou a cidade de São Paulo. Já no seu primeiro LP (1968), o tema da cidade voltava a ser cantado em "Não buzine que estou paquerando", uma crônica mundana que tem como palco a grande cidade, seu ritmo veloz e suas ruas pulsantes:

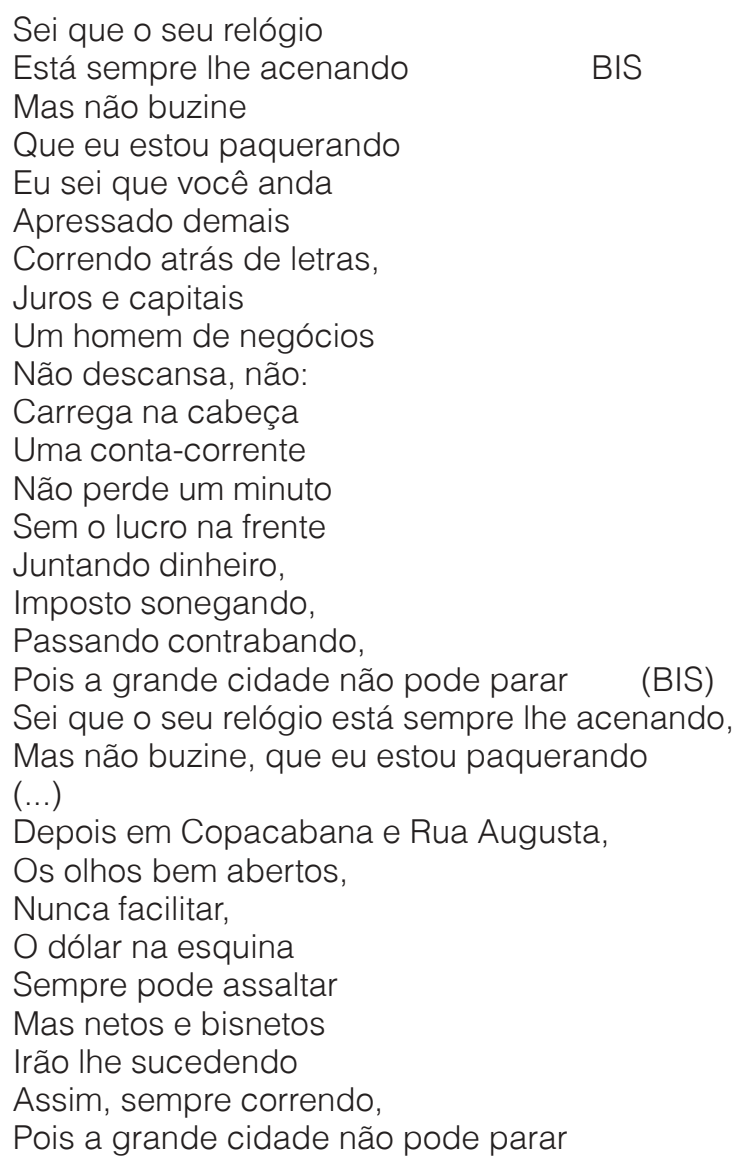

11 PERRONE, Charles. Op.cit. 
Tom Zé faz a elegia de um outro tempo de fruição das ruas da cidade, tendo como interlocutor um burguês capitalista, figura citadina típica. A grande cidade "não pode parar", alude ao slogan da época, preferido dos paulistanos mais exortativos: "São Paulo não pode parar". Mas, no plano poético, o conflito entre o tempo da paquera e o tempo dos negócios se resolve em favor do primeiro. Observa-se um nítido diálogo com os temas da Jovem Guarda, seus carrões, seus lugares ("Rua Augusta") e paqueras. Mas o playboy competitivo e agressivo, personagem paradigmático das canções da Jovem Guarda, dá lugar ao timing desacelerado da vida urbana, mais próximo talvez do movimento hippie.

Em outra canção, o baiano de Irará se inspirou nos edifícios monumentais que formavam a paisagem paulistana desde os anos 50, para compor uma de suas canções mais surrealistas: "A briga do Edifício Itália com o hotel Hilton". A letra, despretensiosa e ingênua num certo sentido, acaba por realizar uma desmonumentalização dos Edifícios, ao mesmo tempo que os humaniza, impregnando-os de qualidades e idiossincrasias, como ciúmes, competição e vaidade. Tal como duas vizinhas encrenqueiras e competitivas, a briga do Edifício Itália e o Hilton Hotel, símbolos do poderio e do fausto da cidade, acabam por lembrar-nos que a cidade, alienada de si mesma, ainda carrega uma humanidade latente, expressa de forma singela e nada elegante - uma briga de vizinhos - acabando por perturbar a racionalidade e a ordem instauradas pela busca da eficiência capitalista. Neste sentido, Tom Zé realiza uma operação de descontrução da faceta mais famosa de São Paulo: a cidade fria e impessoal, coração do capitalismo selvagem brasileiro.

\title{
A briga do Edifício Itália e do Hilton Hotel ${ }^{12}$ (Tom Zé)
}

\author{
O Edifício Itália \\ era o rei da Avenida Ipiranga: \\ alto, majestoso e belo, \\ ninguém chegava perto \\ da sua grandeza. \\ Mas apareceu agora \\ o prédio do Hilton Hotel \\ gracioso, moderno e charmoso \\ roubando as atenções pra sua beleza. \\ O Edifício Itália ficou enciumado \\ e declarou a reportagem de amiga: \\ que o Hilton, pra ficar todo branquinho \\ toma chá de pó-de-arroz.
}

12 TOM ZÉ(1972)Continental SLP 10084.Relançado em 1984 com o título "Se o Caso é Chorar". 
Só anda na moda, se veste direitinho e se ele subir de branco pela Consolação até no cemitério vai fazer assombração o Hilton logo logo respondeu em cima: a mania de grandeza não te dá vantagem veja só, posso até ser requintado mas não dou o que falar Contigo é diferente, porque na vizinhança apesar da tua pose de rapina já andam te chamando Zé-Boboca da esquina

E o Hilton sorridente disse que o Edifício Itália tem um jeito de Sansão descabelado e ainda mais, só pensa em dinheiro não sabe o que é amor tem corpo de aço, alma de robô, porque coração ele não tem pra mostrar Pois o que bate no seu peito é máquina de somar.

O Edifício Itália sapateou de raiva rogou praga e até insinuou que o Hilton tinha nascido redondo pra chamar a atenção abusava das curvas pra fazer sensação e até parecia uma menina louca Ou a torre de Pisa vestida de noiva

No ano seguinte, 1973, Tom Zé apropriou-se novamente de marcos famosos da cidade, para humanizar seus espaços. Neste caso, três das ruas centrais mais famosas - Augusta, Angélica e Consolação - são cantadas como se fossem três mulheres caprichosas. Além delas, Tom Zé faz jogo de palavras com o Largo dos Aflitos e com a Estação da Luz, dois marcos importantes do Centro. Nesta canção, o jogo poético entre o significante e o significado reitera o procedimento de humanização de ruas e espaços que, a princípio, deixam de ser marcos racionais e utilitários e ganham novo sentido em meio a uma geografia afetiva que se manifesta, acima de tudo, pela resignificação de nomes de ruas, praças, logradouros e edifícios. 


\title{
Augusta, Angélica e Consolação ${ }^{13}$
}

\author{
Augusta, graças a Deus, \\ graças a Deus, \\ entre você e a Angélica \\ eu encontrei a Consolação \\ que veio olhar por mim \\ e me deu a mão. \\ Augusta, que saudade, \\ você era vaidosa, \\ que saudade, \\ e gastava o meu dinheiro, \\ que saudade, \\ com roupas importadas \\ e outras bobagens. \\ Angélica, que maldade, \\ você sempre me deu bolo, \\ que maldade, \\ e até andava com a roupa, \\ que maldade, \\ cheirando a consultório médico, \\ Angélica. \\ Quando eu vi \\ que o Largo dos Aflitos \\ não era bastante largo \\ para caber minha aflição, \\ eu fui morar na Estação da Luz, \\ porque estava tudo escuro \\ dentro do meu coração
}

Entretanto, a geografia afetiva elaborada sob a ótica da paródia e da ironia, também podia conviver com uma poética mais direta, sensibilizada por um problema cada vez maior que passou a marcar as visões sobre São Paulo a partir dos anos 70: a degradação ambiental. Mesmo neste caso, a cidade é tratada como uma pessoa doente, um corpo orgânico que padece do descaso e reclama um tratamento mais "humano", numa operação poética de antropomorfização, procedimento que parece demarcar as imagens poéticas de Tom Zé sobre a cidade de São Paulo. 


\section{Botaram tanta fumaça ${ }^{14}$}

Botaram tanto lixo,

botaram tanta fumaça,

Botaram tanto lixo

por baixo da consciência da cidade,

que a cidade

tá, tá tá tá tá

com a consciência podre,

com a consciência podre.

Botaram tanto lixo,

botaram tanta fumaça,

Botaram tanta fumaça

por cima dos olhos dessa cidade,

que essa cidade

tá, tá tá tá tá

está com os olhos ardendo,

está com os olhos ardendo.

Botaram tanto lixo,

botaram tanta fumaça,

botaram tanto metrô e minhocão

nos ombros da cidade,

que a cidade

tá, tá tá tá ta.

Está cansada,

sufocada,

está doente,

tá gemendo

de dor de cabeça,

de tuberculose,

tá com o pé doendo,

está de bronquite,

de laringite,

de hepatite,

de faringite,

de sinusite,

de meningite.

Está, se...

ta tá tá tá tá

com a consciência podre.

Botaram tanto lixo,

botaram tanta fumaça,

botaram tanta preocupação

nos miolos da cidade

que a cidade

tá, tá tá tá tá

está de cuca quente.

14 TODOS OS OLHOS(1973) Continental - 1012 


\section{São Paulo tropicalista no cinema}

Em que pese a importância do tropicalismo musical e, particularmente, a poética desenvolvida por Tom Zé para cantar a cidade, foi o tropicalismo cinematográfico que produziu a obra mais impactante sobre São Paulo, sintetizado na obra "O bandido da Luz Vermelha", de Rogério Sganzerla (1968). Neste caso, as contradições e dilemas não são temperados por um olhar afetivo, mas exacerbados por uma poética visual que aponta para o caos, de consciência de si e do espaço urbano, como resultado da vida urbana num contexto de subdesenvolvimento capitalista. Como escreveu Luiz Zanin Oricchio: "Um dos pontos marcantes do cinema dito "marginal", Bandido baseia-se num caso real, o do assaltante João Acácio, tido como galã pelas vítimas. Mostra uma cidade em transe, literalmente. Independentemente dos méritos artísticos do filme, deve-se reconhecer que poucas vezes São Paulo, como protótipo da cidade nervosa, foi retratada de forma tão fiel. O trânsito nas ruas, o movimento das pessoas, o desequilíbrio visual da arquitetura tudo isso é tratado como um jorro visual criativo, entrecortado, cheio de paródia, ironia e raiva. Esse tom refletia não apenas a dura experiência da vida na cidade, mas um momento particular na vida da nação quando a opção política fora descartada, restara o escracho e o desespero. Infelizmente, a paisagem de São Paulo era a ideal para representar esse estado de espírito" 15 .

O próprio diretor do filme destacou a importância da encenação da metrópole dentro da sua obra: : "O meu trabalho se propunha a ser uma comédia criminal. Era o primeiro esforço para se fazer um retrato falado da grande metrópole. É quase trágico este faroeste do Terceiro Mundo.(...) O crítico Francisco de Almeida Salles chamou O Bandido da Luz Vermelha de ópera-bufa sobre a cidade de São Paulo"16

No filme, a opulência paulistana, seus lugares e personagens, é desconstruída sob a ótica de um anti-herói - o bandido João Acácio, que dá título ao filme e que existiu na vida real. Ele perambula pelas ruas da chamada "Boca do Lixo", demarcada pelos quarteirões centrais degradados, abrigo de prostitutas e meliantes. Pouco se vê da "metrópole moderna" decantada pela ideologia desenvolvimentista e pelo ufanismo da elite paulistana. O "lixo" funciona como uma alegoria para a encenar o monstro urbano, subproduto de uma modernização predatória e periférica. Ismail Xavier destaca a cena final, que se passa justamente num dos muitos "lixões" da cidade: "Este retorno [ao lixo ] marca uma sime-

15 Luiz Zanin Oricchio, Estadao.com.Br , acessado em 14/08/2004

16 Rogério Sganzerla, 1990, apud Contracampo - Revista de Cinema (http://www.contracampo.com.br/58/ aluzdobandido.htm) acessado em 14/8/2004 
tria dentro do plano alegórico de O Bandido da Luz Vermelha e trabalha novamente com um dos seus emblemas: o lixo. No começo, eram as imagens movimentadas a sublinhar o binômio pobreza-violência. Agora é o espaço rarefeito, ausência de ação. Compõe-se o cenário para a melancolia do herói que canta (...) enquanto o ouvimos, uma série de planos gerais nos traz a favela como reduto de passo lento oposto à agitação da cidade"17.

O fracasso humano e a cafajestice do "bandido da luz vermelha" adquirem uma dimensão histórica mais ampla, alegorizando o fracasso da própria modernização brasileira, a partir da encenação da "Boca do Lixo" paulistana. Ao contrário das descontruções das imagens da brasilidade idílica, representadas por Rio e Bahia, a "brasilidade" pontuada a partir de São Paulo não ilude a ninguém, com seus mitos de autenticidade e originalidade, apresentando-se tal como é: subdesenvolvida e periférica. Ao contrário da revolução que nasceria do sertão e do morro, tal como a arte de protesto típica dos anos 60 pregava, a "explosão do terceiro mundo" a partir da alegoria da Boca do Lixo paulistana, não irá redimir e modernizar a nacionalidade. Os espaços e personagens (sub)urbanos anunciam apenas o apocalipse e o caos. No limite, a perspectiva de Sganzerla parece afastar-se da tradição inaugurada pelo modernismo, a de cantar a grande cidade em seus contrastes, mas a partir de um olhar, em última instância afetivo. Neste sentido, Tom Zé seria mais fiel à tradição do modernismo.

\section{Considerações finais}

Portanto, o movimento tropicalista gerou, ao menos, duas imagenssíntese da cidade que, se não podem ser tomadas como auto-excludentes são, no mínimo, divergentes. Na sua vertente musical (neste caso representada por Tom Zé) esboça-se uma geografia afetiva que procura desconstruir a cidade, resignificando os nomes de ruas, marcos e edifícios, humanizando seus espaços e monumentos de pedra. No tropicalismo cinematográfico, o olhar de Sganzerla vai para outra direção, radicalizando a imagem de São Paulo como síntese do choque arcaico-moderno, produzindo um "senso onipresente de periferia". Na obra de Tom Zé a ironia está a serviço da humanização do espaço urbano, a princípio frio e monstruoso. A cidade sem rosto ganha qualidades humanas pela resignificação dos nomes que demarcam seus espaços e monumentos. A cidade ganha uma nova centralidade, renovando uma promessa de utopia libertária a partir de uma nova consciência individual. Na obra de Sganzerla, a ironia está a serviço da desmistificação da história, vista

17 XAVIER, Ismail. Alegorias do subdesenvolvimento. São Paulo, Brasiliense, 1993, p.. 76. 
pela cultura política dos anos 1960 como a caminhada para a libertação coletiva. A cidade perde sua centralidade: a monumentalidade moderna dos prédios, imagem oficial de São Paulo, é substituida pelos espaços claustrofóbicos da "Boca do Lixo" e pelo vazio dos "lixões" periféricos. A cidade sem centro, anuncia a história sem utopia.

Ambas perspectivas, mesmo situadas em pólos de consciência diferenciados, parecem traduzir os limites da ideologia do progresso que conduziu o crescimento paulistano sem maiores autocríticas até meados dos anos 1960, elogiando a expansão no espaço e a evolução no tempo. No final dos anos 1960 e no início dos anos 1970, a ville tentaculaire que assombrava Mário de Andrade começava a abraçar a si mesma, fagocitando o espaço e o tempo do progresso ilimitado. Seja renovando o olhar lírico sobre a cidade, seja anunciando o apocalipse urbano, a Tropicália chamou a atenção para os efeitos colaterais da nossa modernização capitalista, processo no qual a cidade de São Paulo ocupa um lugar de monumento e ruína.

\section{REFERÊNCIAS BIBLIGRÁFICAS}

DUNN, C. Brutality Garden: tropicália and the emergence of a Brazilian counterculture. Chapel Hill: University of North Carolina Press, 2001, 276 p.

FAVARETTO, Celso. "Tropicália: política e cultura" IN: Naves, S. et alli. Do samba canção à tropicália. Relume-Dumará / FAPERJ, 2003, 246-247

NAPOLITANO, M. "A arte engajada e seus públicos". Estudos Históricos, Rio de Janeiro, 28, p. 103-124, 2001

PERRONE, Charles. "Performing São Paulo: vanguard representations of a Brazilian Cosmópolis". Latin American Music Review vol. 23, no. 1 (2002), 60-78

RISÉRIO, Antonio. Avant-Garde na Bahia. Salvador, Instituto Lina Bo Bardi, 1995, 260 p. VELOSO, Caetano. Verdade Tropical. São Paulo, Cia das Letras, 1998, 524 p.

VILLAÇA, M. Polifonia Tropical: experimentalismo e engajamento na música popular (Brasil e Cuba, 1967-1972). São Paulo, Humanitas/História Social-USP, 2004, 295 p.

XAVIER, I. Alegorias do subdesenvolvimento. Cinema Novo, Tropicalismo, Cinema Marginal. São Paulo, Brasiliense, 1993, 281 p. 